


\section{Introduction}

During the summer of 1905 many of the trees in the Wausau trial orchard were found to be suffering from some disease.

In the case of many of the Northwestern Greening trees the foliage on one or more of the larger branches appeared dwarfed and wrinkled and later turned brown but did not fall.

On examination it was found that these branches were girdled at the base or point of union with the trunk. The bark in the erotches was brown and sunken, the injury extending through the cambium to the sap wood.

Further investigation in the orchard showed hundreds of trees to be affected, some like the Northwestern in the erotches, others having large patches of dead bark on the trunks.

It was not until the close of the growing season that it was definitely determined that the trouble was caused by the apple tree blight canker. It has since been found that the disease is widely prevalent in the state, having been found in twenty-six counties and probably exists in the majority of young orchards throughout the state, attacking the crotches and trunks of young apple trees.

The apple tree blight canker and methods of treatment were fully deseribed by $\mathrm{H}$. H. Whetzel, plant pathologist, Cornell University, at the 1906 annual meeting of this Society and the address printed in the 1906 Annual Report.

That a better knowledge of the disease and the means of combating it may be had the article is here reprinted.

F. Cranefield, Secretars. 


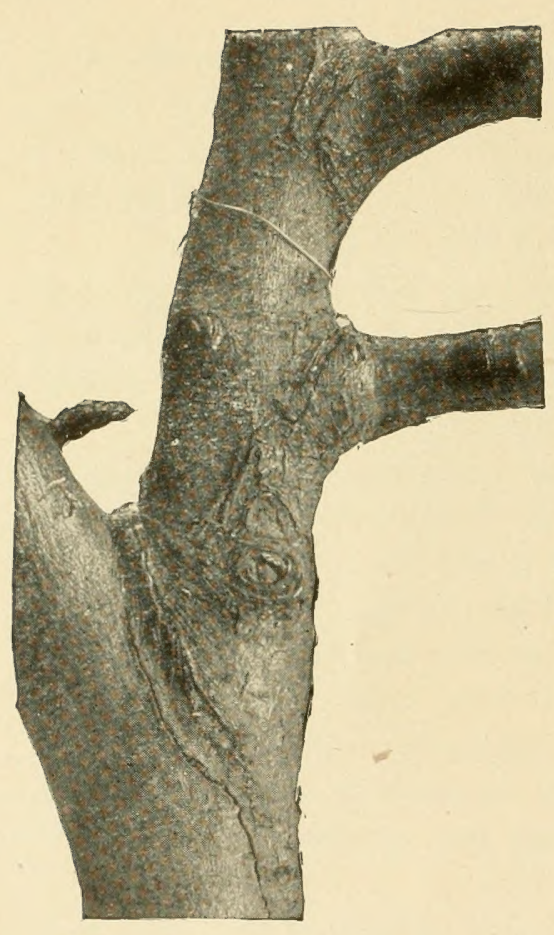

FIG. 1-Typical blight canker on main limb of young tree.

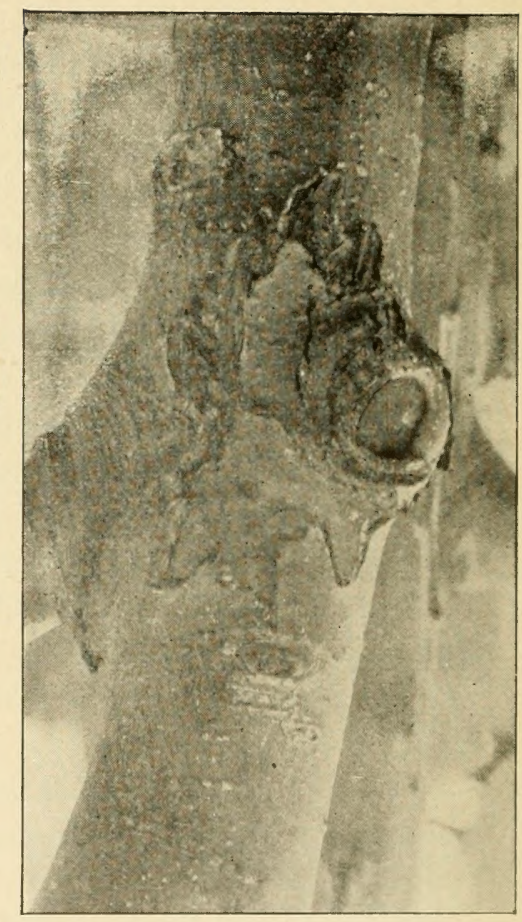

FIG. 2-Typical canker showing the erack about the margin where the diseased bark has dried away from the healthy tissue.

Note-Figs, 1 to 13 inclusive from Bulletin 236, Cornell University, Ithaca, N. Y. Figs. 14, 15, 16 and 17 from photographs of trees in the Wausau Trial Orehard. 


\title{
The Blight Canker of Apple Trees
}

\author{
H. H. WHETZEL.
}

During recent years several kinds of cankers oceurring especially upon apple and pear trees have been described and figured in bulletins from different experiment stations in this country. By careful inoculation experiments these various cankers have been shown to be due to different species of either fungi or bacteria. Growers very generally even at the present time attribute such injuries to "sun scald" or "freezing." Lack of knowledge of the nature of fungous and bacterial growths, together with the ease with which responsibility may be shifted upon the weather, has made this opinion the common and natural one. Not only have experiment station workers shown that these injuries are usually due to the attacks of living organisms rather than to the results of weather conditions, but they have demonstrated that the different forms of these cankers are due to distinctly different organisms.

The term "canker" then has come to be a very general one and is applied to diseases which cause the death of definite areas of bark on the limbs and bodies of trees. At least six distinet canker diseases of apple and pear trens have been described and figured in recent years. Fach of these cankers have been proven to be due to distinctly different kinds of fungi. In this paper, however, we shall deal with a canker disease, not caused by a fungus and differing strikingly from those already mentioned. To this disease I have given the name of blight canker.

THE DISTINGUISHING CHARACTERS AND APPEARANCE OF THE CANKER.

The blight canker while it may oceur on trees of almost any age is most destructive on young trees just coming into bearing, trees from 8 to 15 years old. Old trees weakened by age and 
neglect may suffer seriously from its attacks and the dead limbs protruding here and there from the green foliage in old orchards are often to be attributed to the ravages of this canker.

In young trees with smooth bark the eankers are easily detected even in their first stages. They appear as discolored and

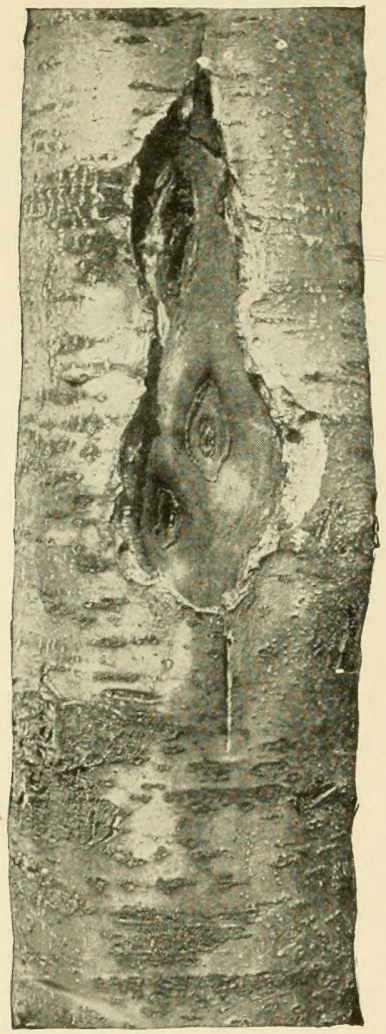

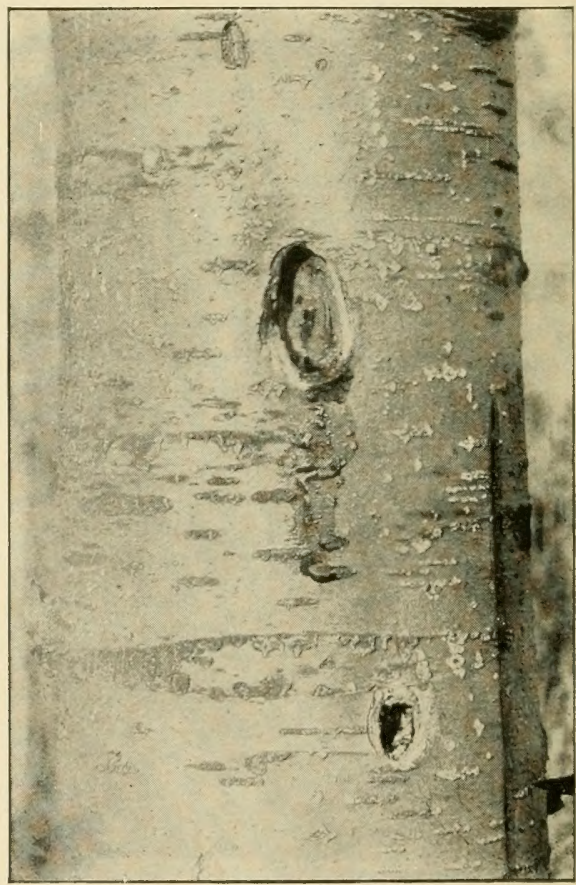

FIG. 4-Typical pit cankers in the body of a tree from which the diseased bark has dropped out. The upper one is exuding sap,-“" bleeding."

FIG. 3-Cankers in body of tree resulting from the renewal of activity season after season. Observe that these started from small pit cankers which partially healed each season. The disease the following season destroyed all the bark growth, leaving only the little bit of wood formed in the callus. This still persists.

somewhat shrunken areas, the margin along the advancing front being usually slightly raised or blistered. The tissue in actively spreading cankers is of a darker green than the healthy bark and is very watery or sappy. On damp cloudy days drops of a milky, sticky fluid exude from the eankered tissues through 
the lenticles or pores in the bark. After a short time the diseased tissue begins to turn brown and dry out. Unless in a very active state of progress the margins are quite distinct, marked by a crack where, in drying, the diseased tissue has separated from the healthy bark. The older cankers are brown. somewhat darker than the healthy bark. They are distinctly sunken. The surface is smooth, never checked or roughened or beset with pustules or pimples, except in the old cankers where after a time rot fungi gain entrance and thriving in the already dead tissue produce their fruit bodies on the surface. The progress of the spreading canker depends largely upon the continuation of favorable weather conditions, which seems to be a humid atmosphere and cloudy days. With the return of bright, sumny weather the active spread of the canker is checked abruptly, cften to be resumed again with the return of favorable conditions. This checking and renewing of activity sometimes results in large cankers with concentrically arranged eracks within the cankered area. This renewal of activity may take place during the same season or the canker may partially heal over to spread anew the following year. A large per cent of the cankers are active during but one season. There are always some, however, in which the disease is perennial, living through the winter to become active again the following spring, spreading and enlarging the original limits of the cankered area. These "hold over" "ankers, as they are called, are the dangerous ones. They are the source of infection for the following year. The diseased bark is usually killed to the wood, to which it clings tenaceously the first season. It gradually decays, however, and falls out, leaving the wood bare and exposed. In small cankers, the cone of diseased bark may be quickly forced out by the rapidly forming calluses which heal and elose the canker wound. In some cases the canker is superficial, never reaching the cambium except perhaps in a limited area at the point of infection. Such wounds heal quickly beneath the dead bark which elings to the tree as a sort of scab.

The cankers vary in size from half an inch in diameter to as much as a foot or more in length and several inches across. On 
healthy, vigorous trees they are small and more or less cireular in outline. They form funnel-shaped wounds with the small end at the cambium. These I have designated as "pit cankers." Often the dead bark remains as a sort of lid to the pit but it is easily removed with the finger or a knife blade. I have seen young trees with limbs and bodies literally covered with these

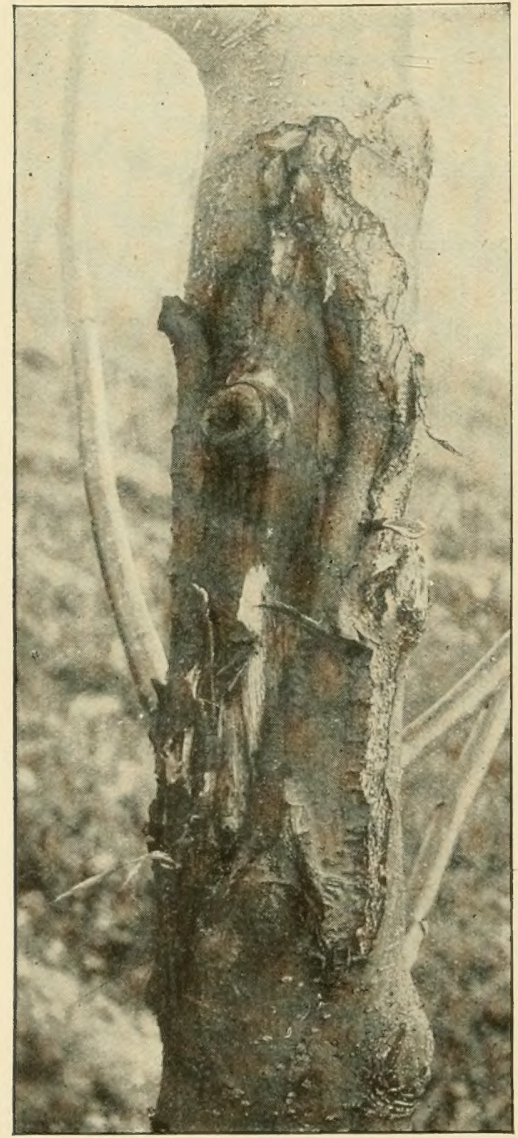

FIG. 5-Large body eanker resulting from successive seasonal attacks of the disease. Originated at the pruned stub.

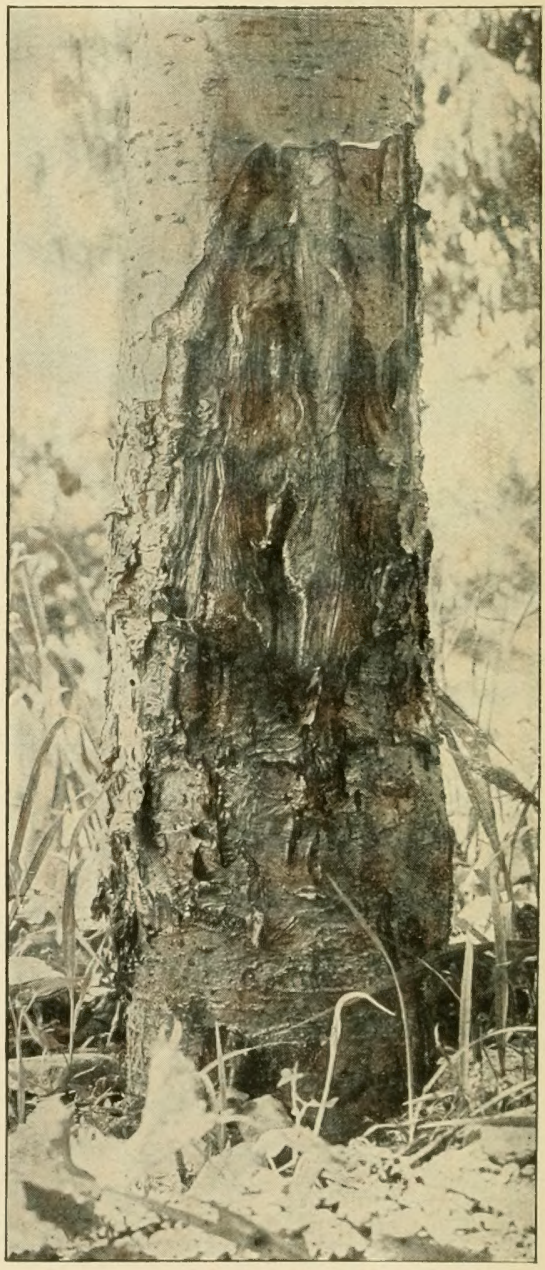

Fig. 6-Large body canker near base of tree, often referred to as "collar rot." The tree has made repeated attempts to heal this wound, 
pit cankers in all stages of healing over. Aside from affording an entrance to rot fungi such eankers unless they enlarge do not seem to seriously affect the health of the tree. In many cases these pit cankers do not heal properly or at all and the disease spreading the same or the following season forms the large and dangerous "limb" or "body cankers."

"Crotch cankers" usually appear in the crotches where the main limbs arise from the body but may also appear in the secondary crotches well up in the tree. In general characters they are similar to the limb and body cankers. Owing to their peculiar position water is retained more readily in the dead bark, thus affording the very best of conditions for the entrance and growth cf rot fungi. These find easier access to the heart wood at the crotch than on the limbs. It was observed that these crotch cankers heal much less readily and successfully than do the limb and body cankers. Crotch cankers unless promptly attended to means the almost certain destruction of the trees.

The large cankers at the bases of young trees frequently referred to by growers as "collar rot" are in many cases very probably due to the same cause as that of the cankers on the upper parts of the tree.

HOW THE DISEASE AFFECTS THE TREE.

The effect of the blight canker upon the tree is to lower its vitality to a greater or less degree by cutting off the food supply to the roots and thus indirectly reducing the flow of sap to the branches and leaves. In other words, it acts the same as "girdling." The "collar rot" and "crotch eankers" seem to be the most fatal to the tree. The effects of the canker are first evidenced in the foliage. If there is a large body canker the entire tree may show the effects of the trouble. More often the first symptom noted by the grower is the peculiar appearance of the foliage on one or more of the limbs. Either these branches fail to leaf out at all in the spring, or if they do the leaves never fully expand but remain undersized and curled or inrolled. They never take on the dark green color of healthy 
foliage, remaining pale and gray. Growers often refer to such trees as having "mouse ear" leaves. As the season advances and the cankers spread, the leaves often die and dry up on the

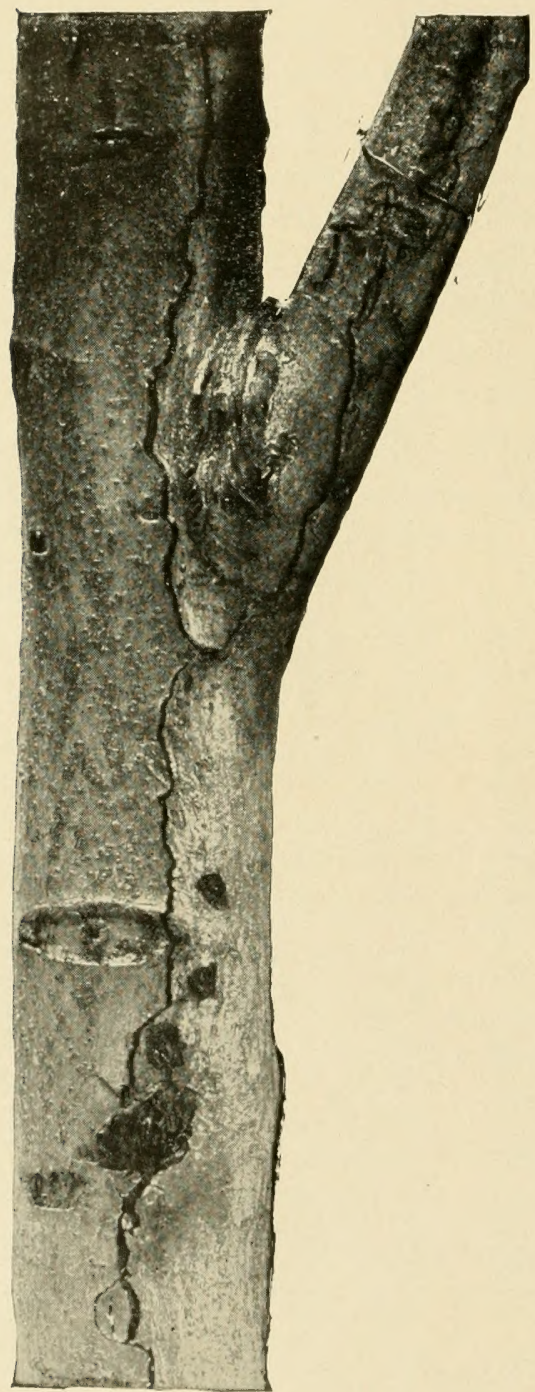

FIG. 7-Canker on pear tree resulting from inoculation with bacteria from active canker on apple tree.

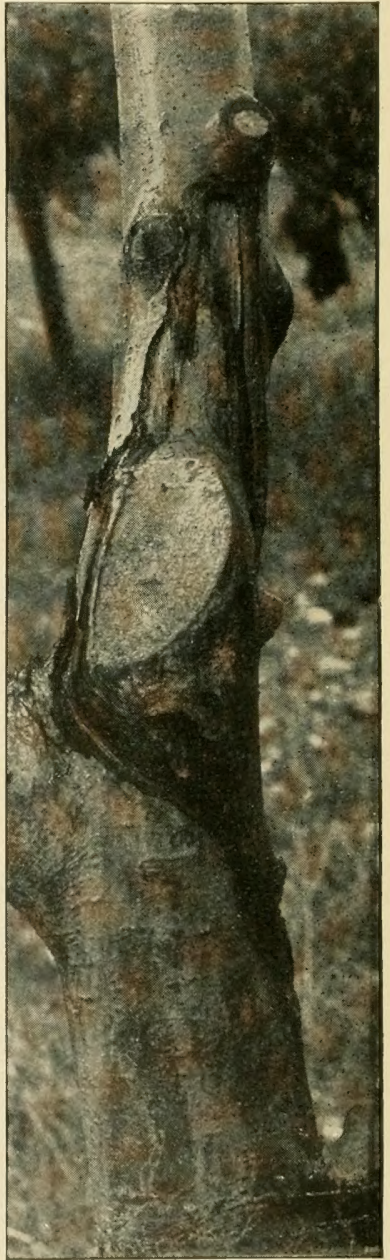

Fig. 8-Pruned stub canker that has spread down side of limb during early spring of second year. Diseased tissue cleaned away, traated with corrosive sublimate and painted. Good calluses formed. Canker ceased to spread. 
branches. Sometimes badly affected trees will pull through mutil autumn or even live for two or three seasons. Such trees have seanty foliage, blossom profusely and frequently set a heavy crop of fruit. This fruit falls prematurely or is small and inferior in quality.

Such affected limbs and trees, as if in anticipation of their approaching death, seem to devote their expiring energy to one

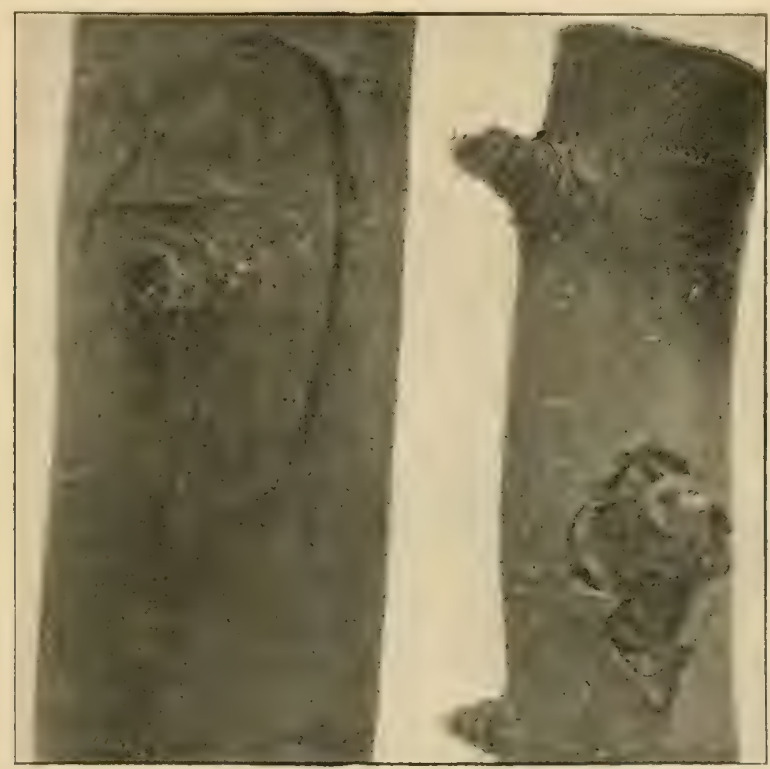

FIG. 9-Canker on limbs of apple which originated through blighted spurs.

grand and final effort to reproduce themselves. As already stated, where the trees are strong and vigorous they frequently suceed in promptly healing the canker wounds. The dead bark of the eanker makes, however, an exeellent infection court for the entrance into the tree of "heart rot" and other decay inducing fungi. Moisture so necessary to the germination and growth of the spores of fungi, is retained for a considerable time in the dead tissue. This is more especially true of croteh cankers. No doubt these rot fungi are often to blame for the final death of the tree. The heart wood of badly aftected limbs and trees is commonly found to be soft and rotten with only a thin rim of sound sap wood surrounding it. 
THE CAUSE OF THE CANKER.

A mieroseopic examination of the viscid milky drops that exude from freshly cankered surfaces on moist, cloudy days will show them to be composed almost entirely of minute rod-shaped bacteria. The diseased tissue within the bark will also be found to be alive with these minute plants. By their rapid growth and multiplication within the cells of the bark they cause its

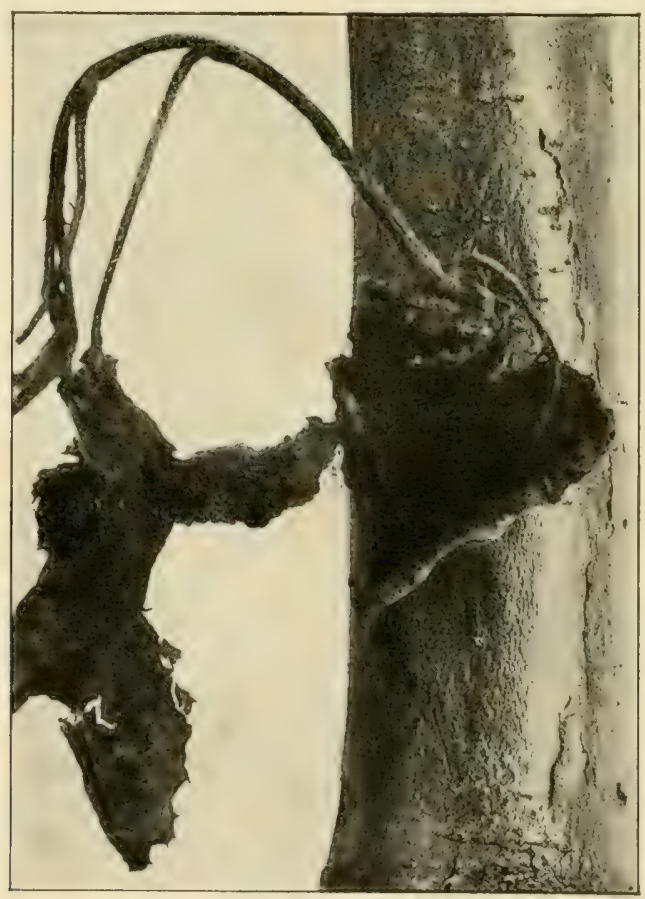

FIG. 10-Recently blighted shoot on limb of Greening apple tree with well marked active canker about its base.

death. They are not carried along in the sap but slowly work their way from cell to cell. When the canker dries down they die and disappear so that examination of the tissue of old cankers does not show them. That they are the direct cause of the disease was proven in the following manner: Bacteria from the cankered tissue was introduced into the bark on the body of a healthy apple tree and also into the bark of a healthy 
pear tree, with the result that typical cankers appeared in both cases. Blossoms and growing twigs of both pears and apples were also inoculated with bacteria from this same canker. These nearly all developed good cases of blight in about ten days, while twigs and blossoms punctured with a sterile needle gave no infection. This last experiment was twice repeated during

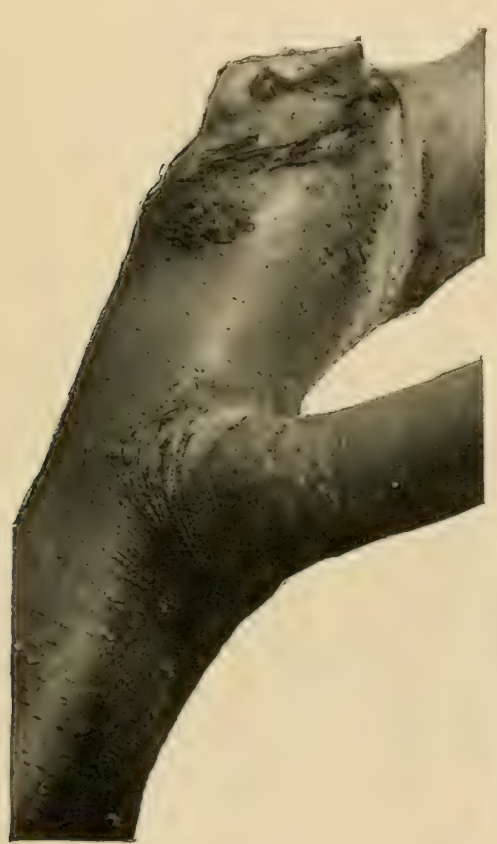

Fig, 11-Pruned stub canker. Infected at time of pruning, probably by the saw. Note the color of dead bark.

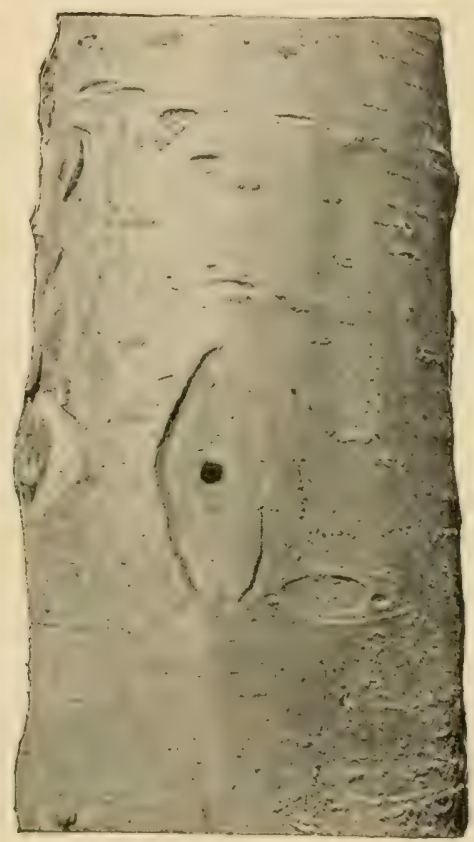

FIG. 12-Canker formed about the mouth of the burrow of a borer near base of an apple tree.

the summer with pure cultures of the bacteria from the apple tree canker. 'The blight resulted in practically every case. Young fruits of both the pear and apple were also inoeulated and gave well developed cases of the disease. By a comparative study in various culture media of the bacteria from cankers, twigs and fruits of both pear and apple obtained from different orehards about Ithaca the organism of the canker was shown to be identical with that of the well-known "fire blight" of the pear and "twig blight" of the apple, Bacillus amylovorous. 
HOW TREES BECOME INFECTED.

Only those ways of infection which personal observation has discovered are here recorded. No doubt the bacteria enter the bark in still other ways than those I have observed.

Early in my investigation I came to the conclusion that the bacteria frequently get into the bark of the limbs and body by way of short spurs and watersprouts. The opinion was fully confirmed later in the season. Twig blight became very prevalent during July and August, especially in the region about Ithaca, $\mathrm{N}$. Y. It was then an easy matter to find blighted spurs and watersprouts with active cankers about their bases. Where these waterspronts grew out from the trunks as is often the case in young trees, typical body cankers were formed. The infection of the sprout itself is generally attributed to the work of insects which after visiting freshly cankered spots or blighted twigs introduce the bacteria into the succulent tissues of the rapidly growing healthy shoots. The blighted watersprout soon dries up and falls away, leaving often a very indefinite scar in the cankered area so that the following season it is usually impossible to te'l with eertainty the manner of infection. Obserration of a large number of trees, during the past season, convinces me that the blighting of adventitious shoots on trunk and limbs is responsible for a majority of the cankers in such lceations. A number of cankers were produced in this way by artificial inoculation.

Another source of infection was found to be the pruming knife. Along one side of an orehard of some 350 trees which was under observation throughout the season, it was early noticed that the pruned stubs of 1904 , especially, showed collars of dead bark often two or three inches in width. Instead of forming a callous and healing over the wound, as would normally ocenr, the tissue had died and shriveled up but still clung to the stub. Tn most eases the bacteria which had caused the death of the bark had died out the first season. In a few instances, however, the canker was ohserved to be active early in the spring, extending down the side of the adjoining limb. 'T'wo 
badly diseased trees on this side of the orehard seem to have been the source of infection. Owing to their diseased condition they had been severely pruned the previous season and very probably the knife or saw had carried the bacteria to the healthy trees. Flies which were observed to constantly follow the pruner to suck up exuding sap may have been the direct agents in many cases in transferring the bacteria. The knife itself may convey the disease, as is shown by the following in-

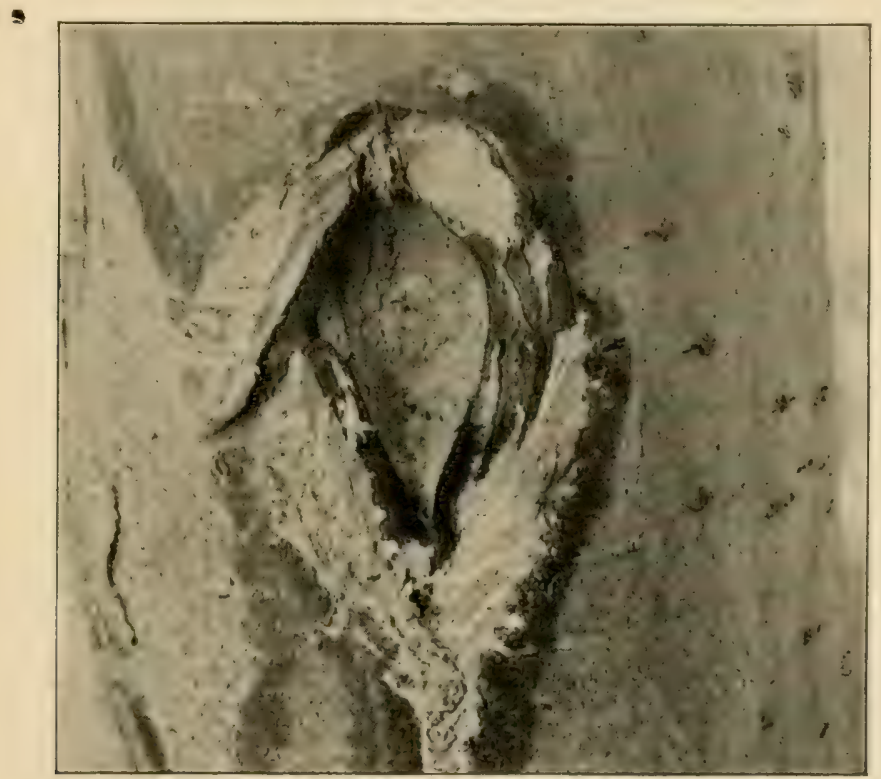

FIG. 13--Body canker cleaned out, treated and painted about eight weeks after treatment. Good healthy calluses formed, which with proper eare will completely heal this wound.

cident: While making inoculations into the body of an apple tree on the station gromds, I had cceasion to remove from near the base a large sprout of several years' growth. 'This I dic with my knife which I had but shortly before used to ent bark from a fresh canker. A typical eanker soon developed about this pruned stub.

Of a similar nature are infections that ocem through wounds or bruises on the limbs and bodies of trees. These wounds, 
commonly known as "barking," may be made by careless workmen when plowing or working about the trees or from the gnawing of animals, one of the worst of which in New York is the woorlchuck. A large per cent of such wounds heal over eventually, but frequently through the ageney of insects or other other means these wounds serve as infection courts for the canker bacillus. An interesting case of wound infection came under my observation this season. In cutting a cankered branch from a tree I accidently "barked" a healthy limb with the cut end of the diseased branch. The tree was not again visited until scme weeks later, when a large and actively spreading canker was found to have developed about the abrasion. The bacteria were found in abundance in the diseased tissue and pure cultures obtained.

The wounds or punctures of insects seem to be directly responsible for some of the infections. Occasionally cankers on the bodies of trees camnot be attributed to infection through blighted shoots. In some cases these cankers have been traced directly to the wounds made by insects. It is probable that many of the cankers at the base of young trees originated in wounds made by borers. One undcubted case of this kind came under my observation last summer. The bacteria are probably carried to these wounds by flies or other insects which visit these places to feed on the exuding sap and exerement. The infecting agents in the ease of crotch cankers have not as yet been definitely located. It seems likely that insects are here again responsible.

I have found them repeatedly hiding in the crevices of the dead bark that accumulates in the crotches, and one species seems to feed to some extent on the living tissues in such places. I have also observed this same species feeding on the exuding sap of cankered limbs and stubs. That it may carry the bacteria to the crotches seems obvious. Besides this many of the crotches are of such a form that they readily retain moisture and thus afford the best of conditions for bacterial growth.

As a general deduction, then, it may be stated that infection occurs only through a wound of some sort. Moreover, the in- 
fection court must be of such a nature that it will not dry out quickly. An abundance of moisture is known to be necessary to the rapid growth and development of the blight organism. This peculiarity accounts for the ease with which growing shoots

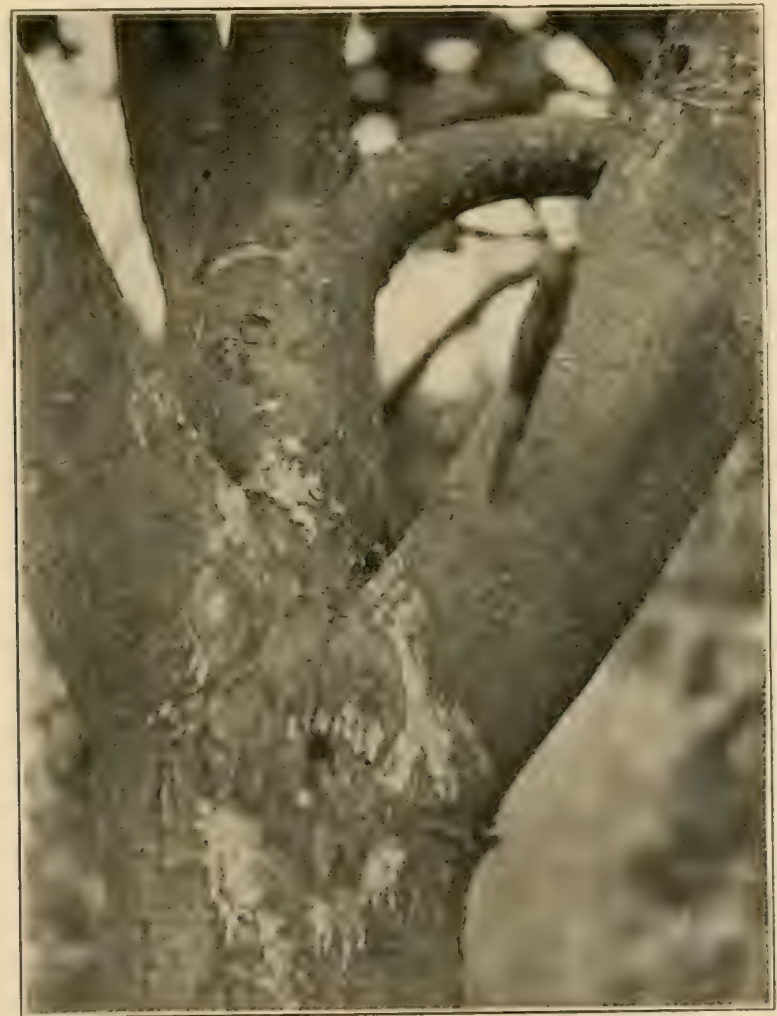

FIG. 14-Crotch cankers, Wausau Orchard. 'Treated July, 1906, but work not thoroughly done. Note the canker extending on central branch. The branch on right is also affected for several inches. Photo, July 1907.

are affected. Where the diseased tissue of an active eanker was at once cut out and the wound exposed to the drying heat of the sun without any other treatment, the canker ceased to spread and the place healed rapidly. 
TREATMENT TIIAT PROMISES BEST RESULTS.

Nhthomgh the work of the past season has been devoted largely to a study of the various manifestations of the disease, its cause and distribution, still some attention has been given to the means of combating it. Prevention rather than cure is one of the axioms of plant pathology. In most cases the curing of a diseased p'ant is impossible or its value does nct warrant the effort required to save it. However, in the case of trees just coming into bearing it seemed that if possible some means of saving them should be worked out. Several things were accordingly tried, but the one that so far gives most promise of definite results is to cut out the cankers. With a sharp knife remove ali the diseased tissue, swab out the wound with a soluticn of corrosive sublimate (one tablet to one pint of water) or with a solution of copper sulphate, $10 \%$ to 2 gallons water, and when dry paint over thoroughly with some heavy lead paint. This should be done early in the season as soon as the cankers are discovered, for two reasons: 1st, the spreading of the canker and its consequent damage to the tree is stopped; and 2nd, the wound is thus given a long period in which to heal. The painting should be repeated again toward the close of the season and again the next year or until the wound has completely healed. This prevents a second infection or the entrance of rot fungi. A bi-monthly inspection of every tree should be made and all cankers carefully cut out and treated as soon as they appear. Cankered trees so treated early in the spring of 1905 have formed good calluses and are fast healing the wounds.

PREVENTIVE MEASURES.

It is scarcely necessary to point out that every precaution should be taken to prevent bruises or injuries of every sort, since these make excellent infection courts for the entrance of the bacteria.

All dead limbs and trees should be promptly removed from the orchard and burmed. Old pear trees in the neighborhood of young apple orehards are often a constant souree of infection 
and unless kent absolutely fire of the blight should be remored. A neighbor careless in respect to blight in his pear trees is a dangerous one.

Cut out and burn every trace of twig blight from both pear and apple trees as soon as it is detected.

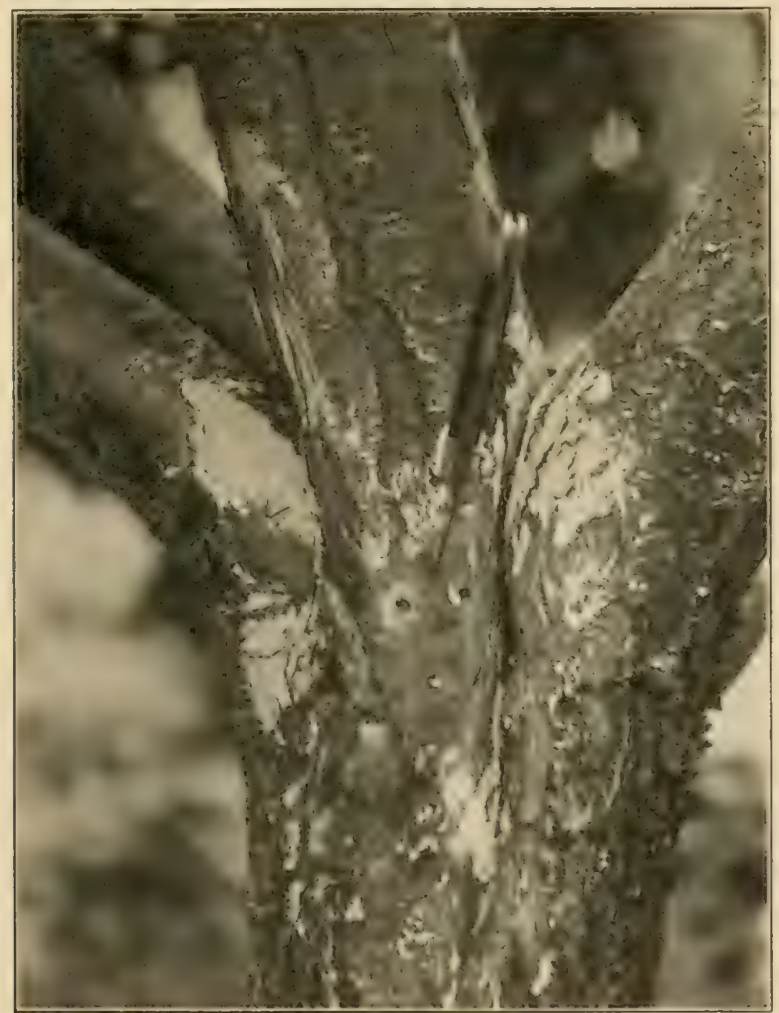

Fig. 15-Croteh canker, Wausan Orchard. Treated July 1906 ; photo, July 1907. Treatment thorough and effective. Canker completely checked and tree saved.

When pruning, treat all cut surfaces with the corrosive sublimate or copper sulphate solution and keep them painted until healed. 'Treat all accidental wounds in the same way.

Keep the body and main limbs of the tree free of watersprouts throughout the summer.

In planting, select trees with open or spreading crotches. 
Avoid excessive fertilizing with nitrogenous manures. Apply some form of phosphoric acid to ripen new growths.

The planting of varieties known to be more or less resistant to this disease is to be recommended. The Wolf River and

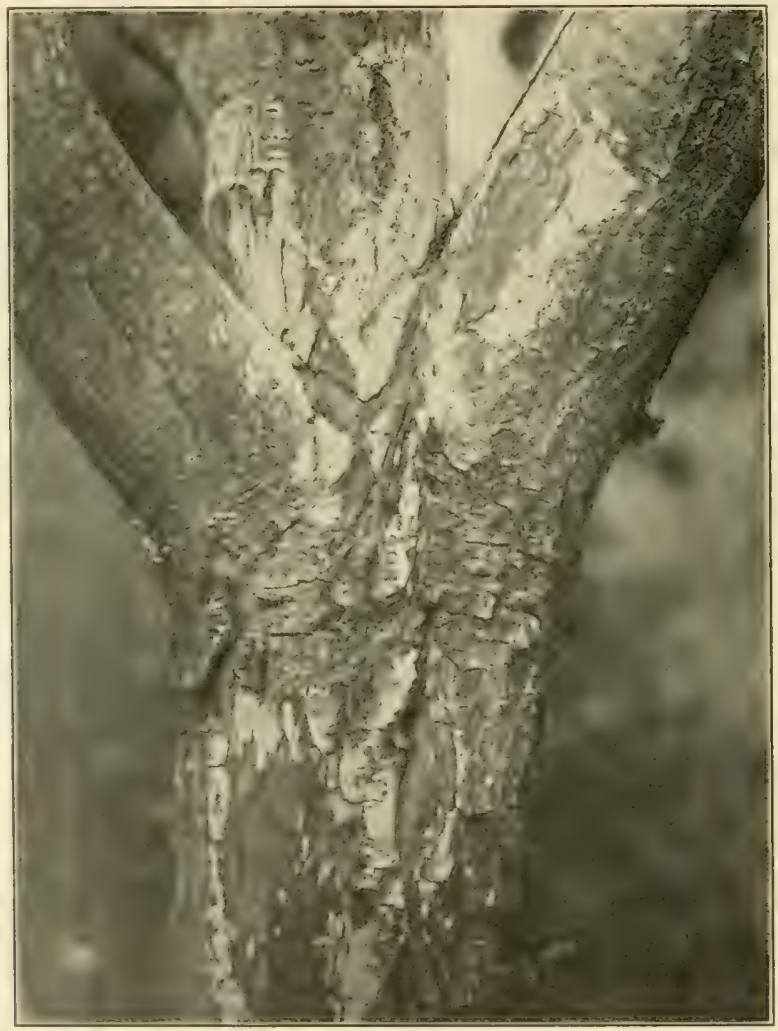

FIG. 16-Results of timely and thorough treatment. Similar to Fig. 15.

T'alman Sweet appear to be of this sort, while Baldwins and Ben Davis suffer most severely. Desirable non-resistant varieties may be top grafted on to resistant stocks.

\section{CONCLUSIONS.}

Injuries caused by blight canker are often ascribed to "sunscald" and "winter-killing."

Blight canker is most often found on young trees, 8 to 15 years old. 
Indicated, in most cases, by discolored and distinctly sunken areas of bark.

When active, eankers exude sticky fluid on warm and cloudy days.

Vary in size from one-half inch in diameter to a foot or more in length.

Frequently found in erotches.

Cuts off food supply; girdles branch or trunk.

Caused by same organism that causes fire blight of pear and twig blight of apple.

Trunks and erotehes may be infected from: watersprouts, pruning knife; punctures of insects; "barking."

Treatment.-Cut out all cankered tissues, disinfect with corrosive sublimate or copper sulfate and cover wounds with paint.

\section{Addenda}

F. CRANEFIELD.

In the spring of 1906 treatement was begun of the affected trees in the Wausau orchard.

It was found that about 100 of the trees were too far gone to warrant treatment and these were removed and the remainder treated as recommended in this bulletin. All cankers discovered were cut out, the wounds scraped clean, disinfected and painted. Pruning knives and gouge chisels were used.

The expense for labor and material was a little over forty dollars.

Over 90 per cent of the affected trees recovered and the entire appearance of the orchard was changed. A few of the trees were so badly affected, over one-half of the circumference of the bark on the trunks being removed, that recovery was delayed. Some of these died the following season and others are slowly recovering.

Had every canker in the orchard been found and treated the disease would have been eompletely eradicated, for a time at least. Naturally, however, some escaped treatment and in oth- 


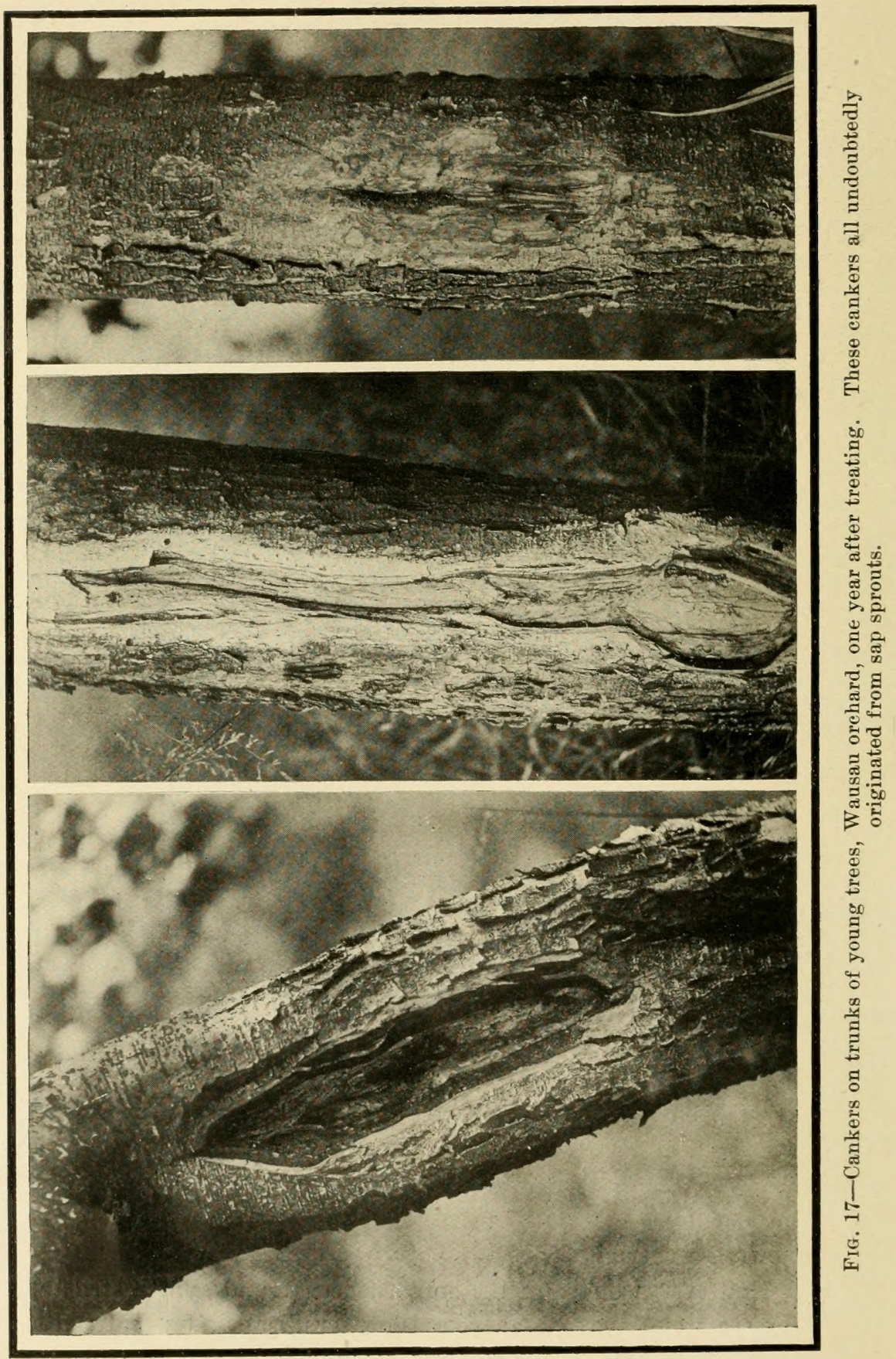


ers the cutting was not severe enough, a little of the affected bark being left to extend the eanker. A case of this kind is shown in Fig. -

When the treatment was thorough the wound began to heal at once, the new bark completely closing the smaller wounds by the end of the season. This caution should then be repeated; cut out all of the diseased tissues. Do not fail to cut to the live cambium, as the wound will soon heal if all of the canker is removed.

The orchard was gone over carefully later in the season and again in the spring of 1907. On the whole the effect of the treatment was remarkable and the orchard probably saved from destruction, for it is but reasonable to assume from the general appearance as a whole and the rapid progress of the disease in 1905 that two or three years more would have sufficed to kill most of the trees.

Observations in 1907 showed plainly that the work must be kept up every season, as many new crotch and pit cankers were found on trees treated in 1906.

The kinds most affected in the Wausau orchard are: Northwestern Greening, Longfield, Wealthy, Duchess, Peerless, Newell, Repka, and Hoadley, about in the order named.

The following were but little affected: MeMahon, Patten Greening, Malinda, Wolf River, Okabena, and Dominion Winter.

Not a single eanker was found on any of the 38 Hibernal trees.

The lesson in this orchard has been somewhat expensive in loss of trees, etc., but may prove very valuable if it results in calling the attention of even a small portion of those who have young apple trees to this most insidious and dangerous of orchard diseases. 


\section{LIBRARY OF CONGRESS}

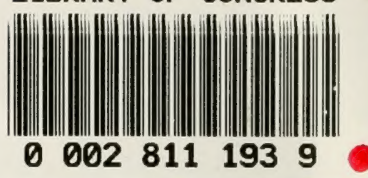

